EKONOMI POLITIK INSTITUSI ZAKAT: SATU PENELITIAN TERHADAP INSTITUSI ZAKAT DI PULAU PINANG

Mohammad Najwa

PRAKTIK KURBAN ONLINE DALAM PERSPEKTIF ISLAM TEBAR HEWAN KURBAN THK DI DOMPET DHUAFA

Reni Noviati

WAKAF SAHAM DITINJAU DARI HUKUM ISLAM DAN PERATURAN PERUNDANGUNDANGAN SETELAH BERLAKUNYA UNDANG-UNDANG NOMOR 41

TAHUN 2004 TENTANG WAKAF

Gusva Havita dan Gestivia Hakim

KARAKTERISTIK ENTREPRENEUR SYARIAH PADA USAHA MIKRO, KECIL, DAN MENENGAH (UMKM) DI BOGOR

Siti Usniah dan Anas Alhifni

ALTERNATIF SOLUSI ATAS PROBLEMATIKA PEMBIAYAAN MUDHARABAH

Rafidah

FAKTOR-FAKTOR YANG MEMPENGARUHI MOTIVASI MAHASISWA MENJADI ENTREPRENEUR SYARIAH

Nur Maulida Hidayat dan Anas Alhifni 
Ketua Editor :

Tuti Kurnia, SP., M.Si

Editor Pelaksana :

H. Sofian Muhlisin, LLB., LLM

Furqonul Haq, SEI., M.EI

Journal Manager :

Wildan Munawar, SEI

Jurnal Syarikah: Jurnal Ekonomi Islam adalah jurnal ilmiah yang diterbitkan untuk mendukung pengembangan ekonomi Islam. Jurnal Syarikah akan memuat artikelartikel yang terkait dengan kajian ekonomi Islam baik kajian teoritis maupun praktis. Redaksi menerima sumbangan artikel, tulisan ilmiah dari para peminat ilmiah kajian ekonomi dan keuangan syariah. Proses editing seperlunya tanpa mengubah maksud dan kandungan tulisan tersebut.

Alamat Redaksi :

Fakultas Ekonomi Islam

Universitas Djuanda Bogor

Gedung B Lantai 4

Jl. Tol Ciawi No.1 Ciawi Bogor Kode Pos 16720

Telp. (0251) 8240985

Email : fei@unida.ac.id 


\section{DAFTAR ISI}

EKONOMI POLITIK INSTITUSI ZAKAT: SATU PENELITIAN TERHADAP INSTITUSI ZAKAT DI PULAU PINANG

Mohammad Najwa

PRAKTIK KURBAN ONLINE DALAM PERSPEKTIF ISLAM TEBAR HEWAN KURBAN THK DI DOMPET DHUAFA

Reni Noviati

WAKAF SAHAM DITINJAU DARI HUKUM ISLAM DAN PERATURAN PERUNDANG-UNDANGAN SETELAH BERLAKUNYA UNDANG-UNDANG NOMOR 41 TAHUN 2004 TENTANG WAKAF

Gusva Havita, Gestivia Hakim

KARAKTERISTIK ENTREPRENEUR SYARIAH PADA USAHA MIKRO, KECIL DAN MENENGAH (UMKM) DI BOGOR

Siti Usniah, Anas Alhifni

ALTERNATIF SOLUSI ATAS PROBLEMATIKA PEMBIAYAAN MUDHARABAH

Rafidah

FAKTOR-FAKTOR YANG MEMPENGARUHI MOTIVASI MAHASISWA MENJADI ENTREPRENEUR SYARIAH

Nur Maulida Hidayat, Anas Alhifni 


\title{
KARAKTERISTIK ENTREPRENEUR SYARIAH PADA USAHA MIKRO, KECIL DAN MENENGAH (UMKM) DI BOGOR
}

\section{THE CHARACTERISTICS OF SHARIA ENTREPRENEUR ON MICRO, SMALL AND MEDIUM ENTREPRISES (SMES) IN BOGOR}

\author{
S. Usniah'1a; A. Alhifni² \\ 1aProgram Studi Ekonomi Islam Fakultas Ekonomi Islam Universitas Djuanda, Jl. Tol Ciawi \\ No. 1, Kotak Pos 35 Bogor 16720, E-mail: siti.usniah@unida.ac.id \\ ${ }^{2}$ Program Studi Perbankan Syariah Fakultas Ekonomi Islam Universitas Djuanda, Jl. Tol \\ Ciawi No. 1, Kotak Pos 35 Bogor 16720
}

\begin{abstract}
This research aims to determine the characteristics of sharia entrepreneur on micro, small and medium enterprises (SMEs) in Bogor. The method used is a qualitative research method with data analysis technique used is phenomenological analysis. The results showed some conclusions that, the first, the business activities are practiced by each SMEs starting from the process of production and marketing processes. The second, based on the results of data processing showed that SMEs already have an honest character, deal fairly or justice, communicative or qualified, glad to help costumers, keep the rights of consumers and give charity, infaq and shadaqah. However, there are a maximum of characters that have not applied in activities such as honesty in maintaining cleanliness when production and keep the rights of consumers to deliver the goods in accordance with orders. The third, the impact of the adoption of the characteristics possessed by each SMEs cause various developments from increased production, sales, revenue and widespread market.
\end{abstract}

Keywords: The Characteristics of Sharia Entrepreneur, SMEs, Business

\begin{abstract}
ABSTRAK
Penelitian ini bertujuan untuk mengetahui karakteristik entrepreneur syariah pada usaha mikro, kecil dan menengah (UMKM) di Bogor. Metode penelitian yang digunakan adalah metode penelitian kualitatif dengan teknik analisis data yang digunakan adalah analisis fenomenologi. Hasil penelitian menunjukkan beberapa kesimpulan yaitu, pertama, kegiatan usaha yang dipraktikan oleh setiap UMKM dimulai dari proses produksi dan proses pemasaran. Kedua, berdasarkan hasil pengolahan data menunjukkan bahwa UMKM telah mempunyai karakter jujur, berbisnis secara adil atau keadilan, komunikatif atau cakap, senang membantu pelanggan, menjaga hak-hak konsumen dan menunaikan zakat, infaq dan shadaqah. Akan tetapi, terdapat karakter yang belum maksimal diterapkan dalam kegiatannya. Ketiga, dampak dari penerapan karakteristik yang dimiliki oleh setiap UMKM menimbulkan berbagai macam perkembangan mulai dari peningkatan produksi, penjualan, pendapatan dan meluasnya pasar.
\end{abstract}

Kata Kunci: Karakteristik Entrepreneur Syariah, UMKM, Bisnis

Usniah, S. 2017. Karakteristik Entrepreneur Syariah pada Usaha Mikro, Kecil dan Menengah (UMKM) di Bogor. Jurnal Syarikah 3(1): 372 - 390. 


\section{PENDAHULUAN}

Usaha Mikro Kecil dan Menengah (UMKM) berperan penting di dalam pembangunan dan pertumbuhan ekonomi, tidak hanya di negara-negara yang sedang berkembang, tetapi juga di negara-negara maju. Selain itu, UMKM juga dapat menopang kekuatan perekonomian negara di dalam menghadapi krisis keuangan global yang dirasakan di seluruh dunia, termasuk Indonesia. Perkembangan jumlah UMKM di Indonesia periode 2012-2013 mengalami peningkatan sebesar 2,41 persen berdasarkan data statistik. Sehingga hal tersebut menunjukkan bahwa UMKM di Indonesia mampu memberikan kontribusi dalam penyerapan tenaga kerja dan pendapatan domestik bruto (PDB) serta membuktikan bahwa UMKM memiliki peran riil yang penting dalam kehidupan perekonomian nasional.

UMKM tidak hanya berfungsi sebagai penyerap tenaga kerja dan penekan tingkat kemiskinan, namun dapat berfungsi sebagai wadah untuk memasarkan wisata daerah dengan berbagai kuliner yang memiliki ciri khas masing-masing. Bogor merupakan salah satu kota penyangga ibu kota Negara. Letaknya yang strategis menjadikan wilayah Bogor baik Kota Bogor maupun Kabupaten Bogor sebagai wilayah transit dan tujuan wisata. Bogor menjadi salah satu tujuan wisata seperti wisata Puncak yang memiliki banyak UMKM dalam berbagai macam sektor baik sektor perdagangan, sektor pertanian dan sektor jasa. Oleh karena itu, wilayah Bogor meningkatkan kinerja sektor UMKM termasuk usaha mikro dan kecil baik secara kualitas maupun kuantitas guna memenuhi kebutuhan masyarakat Bogor.
Banyaknya Usaha Mikro Kecil dan Menengah merupakan implikasi dari sikap kewirausahaan yang dimiliki oleh masyarakat. Namun, UMKM masih memiliki beberapa hambatan dalam perkembangannya. Salah satu yang menjadi penyebabnya adalah karakter pelaku usaha itu sendiri. Hal tersebut ditunjukkan dengan masih banyaknya praktik moral hazard yang dilakukan oleh pelaku usaha yang melakukan kecurangan dalam produksi maupun komposisi bahan baku seperti pada data Badan Pengawas Obat dan Makanan (BPOM) juga menyatakan makanan berformalin masih marak ditemukan. Oleh karena itu, permasalahan tersebut mengindikasikan bahwa masyarakat masih belum memiliki karakter entrepreneur yang sesuai dengan prinsip Islam.

Sebagaimana dalam Islam, kegiatan entrepreneur harus dilakukan berlandaskan aturan-aturan yang sesuai dengan syariah dan Islam telah menempatkan berwirausaha sebagai cara terbaik mendapatkan harta. Sehingga segala kegiatan kewirausahaan harus dilakukan dengan cara-cara terbaik dengan tidak melakukan kecurangan, riba, penipuan dan tindakan kedzaliman lainnya. Karakteristik entrepreneur syariah adalah seorang entrepreneur yang meneladani Rasulullah SAW. Rasulullah merupakan contoh sempurna seorang entrepreneur yang handal dan religius. Keberhasilan Nabi Muhammad SAW dalam berwirausaha dipengaruhi oleh kepribadian diri beliau serta keberhasilan seorang entrepreneur dalam Islam bersifat independen, artinya keunggulannya berada pada integritas pribadinya. Integritas pribadi seorang entrepreneur terlihat pada sifat-sifatnya. 


\section{MATERI DAN METODE}

\section{Usaha Mikro, Kecil dan Menengah (UMKM)}

Usaha Mikro Kecil dan Menengah (UMKM) merupakan unit usaha produktif yang berdiri sendiri, yang dilakukan orang perorangan atau badan usaha disemua sektor ekonomi. Di Indonesia, definisi UMKM diatur dalam Undang-Undang Republik Indonesia Nomor 20 Tahun 2008 tentang UMKM. Berikut definisi dan kriteria UMKM:

1. Usaha Mikro

Usaha Mikro adalah usaha produktif milik orang perorangan dan/atau badan usaha perorangan yang memenuhi kriteria usaha mikro sebagaimana diatur dalam Undang-Undang. Usaha Mikro memiliki kriteria aset maksimal sebesar 50 juta dan omset sebesar 300 juta.

\section{Usaha Kecil}

Usaha Kecil adalah usaha ekonomi produktif yang berdiri sendiri dan dilakukan oleh orang perorangan atau badan usaha yang bukan merupakan anak perusahaan atau bukan cabang perusahaan yang dimiliki, dikuasai, atau menjadi bagian baik langsung maupun tidak langsung dari usaha menengah atau usaha besar yang memenuhi kriteria usaha kecil sebagaimana yang dimaksud dalam Undang-Undang. Kriteria yang digunakan untuk mendefinisikan Usaha kecil adalah usaha yang memiliki kriteria dengan aset sebesar 50 juta sampai 500 juta dan omset sebesar 300 juta sampai 2,5 milyar.

\section{Usaha Menengah}

Usaha Menengah adalah ekonomi produktif yang berdiri sendiri yang dilakukan oleh orang perseorangan atau badan usaha yang bukan merupakan anak perusahaan atau cabang perusahaan yang dimiliki, dikuasai, atau menjadi bagian baik langsung maupun tidak langsung dengan usaha kecil atau usaha besar dengan jumlah kekayaan bersih atau hasil penjualan tahunan sebagaimana yang diatur dalam Undang-Undang. Kriteria yang digunakan untuk mendefinisikan Usaha menengah adalah usaha yang memiliki kriteria aset sebesar 500 juta sampai dengan 10 milyar dan omset sebesar 2,5 milyar sampai dengan 50 milyar.

\section{Karakteristik Entrepreneur Syariah}

Entrepreneur adalah pelaku usaha yang gagah berani mengambil risiko dan yang mampu menangkap peluang serta memiliki inisiatif untuk melakukan inovasi dan cara yang kreatif terhadap pengembangan usahanya. Pada dasarnya, entrepreneur dalam Islam tidak jauh berbeda dengan entrepreneur secara umum. Pentingnya bisnis sebagai pekerjaan seorang muslim maka perlu dibangun wirausaha syariah yang didasari pada sifat-sifat manusiawi dan religius dengan menempatkan pertimbangan agama sebagai landasan bekerja.

Karakteristik entrepreneur syariah adalah akhlak seseorang yang melekat pada jiwa wirausahawan dan membedakannya dengan wirausaha lainnya. Rasulullah SAW dalam menjalankan kegiatan usahanya dilandasi dengan kepribadian yang amanah, pengetahuan luas dan keterampilan yang mumpuni serta karakter-karakter yang dimilikinya adalah jujur, kreatif, berani, percaya diri, tabligh dan istiqamah. Selain itu, integritas seorang entrepreneur syariah ditunjukkan pada sifat-sifat diantaranya yaitu takwa, tawakal, jujur, dzikir, bersyukur, amanah, niat suci dan beribadah dalam melaksanakan usaha, 
menunaikan zakat, infaq dan shadaqah, tekun beribadah, suka bersilaturahim, menyantuni fakir dan miskin, toleransi dan mengakui kesalahan serta bertaubat. Dengan beberapa landasan, maka karakteristik yang akan dijadikan sebagai fokus dalam penelitian adalah sebagai berikut:

\section{Jujur (Shiddiq)}

Shiddiq (benar dan jujur) merupakan perilaku yang didasarkan pada upaya menjadi seorang entrepreneur yang dapat dipercaya. Hal tersebut dapat diwujudkan dalam perkataan, tindakan dan pekerjaan serta tidak ada pertentangan yang disengaja antara ucapan dengan perbuatan. Sebagaimana Rasululah SAW telah memberikan petunjuk mengenai etika dalam berbisnis yaitu salah satunya adalah kejujuran. Kejujuran merupakan ajaran Islam yang sangat mulia khususnya dalam kegiatan muamalah sehingga peran kejujuran dalam melakukan jual beli sangat penting. Dalam dunia usaha, kejujuran ditampilkan dalam bentuk kesungguhan dan ketepatan baik dalam ketepatan waktu, janji, pelayanan, mengakui kelemahan dan kekurangan (tidak ditutup-tutupi) serta menjauhkan diri dari berbuat bohong dan menipu. Bisnis harus didasari atas kerelaan dan keterbukaan atau transparansi antara kedua belah pihak dan tanpa ada pihak yang dirugikan.

2. Bisnis secara adil atau keadilan

Adil adalah prinsip dasar dalam setiap mu'amalah. Adil menurut Islam berasal dari kata 'adl yang secara harfiah merupakan suatu gabungan nilai-nilai moral dan sosial yang menunjukkan kejujuran, kesederhanaan dan keterbukaan. Islam mengorientasikan manusia agar memiliki sikap yang seimbang dan adil dalam konteks hubungan antara manusia baik dengan diri sendiri, dengan orang lain maupun dengan lingkungan dan setiap konsumen juga memiliki hak untuk mendapatkan pelayanan yang benar.

\section{Komunikatif atau cakap}

Komunikatif atau cakap merupakan sikap atau cara seorang entrepreneur menyampaikan suatu pesan baik kepada karyawan maupun kepada konsumen dengan baik sehingga menghasilkan umpan balik (feedback). Setiap entrepreneur sebagai pemimpin harus mampu menggerakan, mempengaruhi, memotivasi, mengajak, mengarahkan, menasihati, menyuruh, membimbing, memerintah, melarang bahkan menghukum agar karyawan atau pekerja mau bekerja demi tujuan yang dingin dicapai dalam usahanya dan mendapatkan ridha Allah SWT. Seorang pelaku usaha atau entrepreneur syariah juga harus mampu berkomunikasi kepada konsumen. Salah satunya yaitu bersikap ramah kepada konsumen agar konsumen merasa puas dengan pelayanan yang diberikan.

4. Senang membantu pelanggan

Entrepreneur syariah harus bersikap khidmah yakni melayani dengan baik. Kegiatan melayani dan membantu pelanggan dalam Islam berorientasi pada sikap ta'awun (tolong-menolong) sebagai implikasi sosial kegiatan bisnis. Pada dasarnya, berbisnis bukan hanya mencari keuntungan material semata, tetapi juga didasari kesadaran untuk memberi kemudahan bagi orang lain dengan menjual barang. Selain itu, Rasulullah juga memperlakukan pelanggan dengan baik seperti halnya beliau memperlakukan dirinya sendiri. Beliau melayani dengan sepenuh hati dan juga sangat mengutamakan kepuasan pelanggan 
5. Menjaga hak-hak konsumen

Sikap yang ditunjukkan Nabi Muhammad SAW dalam membangun kepercayaan konsumen adalah dengan memberikan hak-hak mereka. Hak-hak konsumen diantaranya adalah pertama, hak untuk mendapatkan informasi dan pelayanan yang benar, jujur, adil, mendidik dan terhindar dari pemalsuan. Kedua, tersedianya hak pilih dan nilai tukar yang wajar dan terakhir adalah hak untuk mendapatkan keamanan produk dan lingkungan sehat. Hak konsumen untuk memilih produk merupakan hak khiyar. beberapa konsep dalam transaksi seperti: khiyar majlis, khiyar syarat, khiyar a'ib, khiyar ru'yah dan khiyar ta'yin.

6. Menunaikan zakat, infaq dan shadaqah

Zakat, Infaq dan Shadaqah memiliki persamaan dalam peranannya yaitu dapat memberikan kontribusi dalam pengentasan kemiskinan yang signifikan. Adapun perbedaannya yaitu zakat hukumnya wajib dikeluarkan oleh setiap umat muslim jika harta yang dimilikinya sudah mencapai syarat-syarat harta yang wajib dizakati kepada orang-orang yang berhak menerima zakat (8 asnaf). Sedangkan, Infaq dan Shadaqah hukumnya sunnah dan dapat berupa materiil ataupun non materiil dan diberikan kepada siapapun tanpa ada yang berhak menerima. Menurut pandangan Islam, harta yang digunakan untuk membayar zakat, infaq dan shadaqah tidak akan hilang dan melalui zakat akan membersihkan diri dan mensucikan serta dapat menjadi tabungan kita yang akan dilipatgandakan oleh Allah SWT di dunia dan di akhirat kelak.

Penelitian yang dilakukan oleh Hawa, Gabriela (2014) mengenai "Analisis Karakteristik Wirausahwa Muslim Dalam Upaya Mencapai Kesuksesan Usaha (Studi
Kasus di Sentra Industri Rambak Desa Penanggulangan Kecamatan Pegandon Kabupaten Kendal" dengan menggunakan metode analisis deskriptif kualitatif menyimpulkan bahwa para wirausahawan mempunyai karakter jujur, senang membantu pelanggan, menjaga hak-hak konsumen dan tidak menjelek-jelekkan bisnis orang lain. Akan tetapi, terdapat karakter yang belum maksimal diterapkan dalam kegiatan berwirausaha.

\section{Jenis Penelitian}

Penelitian ini merupakan penelitian kualitatif yang menggunakan metode fenomenologi. Menurut Cresswell (1998) fenomenologi menjelaskan fenomena dan maknanya bagi individu dengan melakukan wawancara pada sejumlah individu. Selanjutnya dihubungkan dengan prinsipprinsip filosofis fenomenologi dan studi ini diakhiri dengan esensi dari makna. (Hasbiansyah, 2008: 170). Metode fenomenologi ini dipilih karena dianggap sesuai dengan penelitian peneliti, yang akan dipakai untuk melihat suatu fenomena yang terjadi pada kegiatan UMKM yang berlangsung di Bogor yang kemudian akan dianalisis dengan karakteristik entrepreneur syariah yang sudah ditentukan oleh peneliti dalam penelitian ini.

\section{Objek Penelitian}

Objek dalam penelitian karakteristik entrepreneur syariah pada UMKM di Bogor adalah UMKM. Sedangkan, subjek yang digunakan dalam penelitian ini adalah pemilik atau karyawan dan konsumen dari UMKM tersebut. Teknik pengambilan subjek penelitian tersebut didasarkan pada alasan dan pertimbangan tertentu yang dapat mewakili sumber data yang representatif. 


\section{Sumber Data}

Sumber data yang digunakan berasal dari data primer dan data sekunder. Datadata tersebut diperoleh melalui:

1. Data primer adalah data pokok yang menjadi sumber dalam penelitian, dilakukan melalui wawancara, observasi. Data primer dalam penelitian ini diperoleh dari hasil wawancara, observasi dan dokumentasi pada tiga UMKM yang meliputi pemilik, karyawan dan konsumennya.

2. Data sekunder adalah data yang digunakan untuk data pendukung dan penunjang dalam penelitian. Data sekunder diperoleh dari buku-buku, jurnal, internet dan bahan pustaka lainnya.

\section{Teknik Pengumpulan Data}

Teknik pengumpulan data merupakan langkah yang paling strategis dalam penelitian, karena tujuan utama dari penelitian adalah mendapatkan data. Teknik pengumpulan data yang digunakan dalam penelitian ini adalah:

\section{Wawancara}

Menurut Esterberg dalam Sugiyono (2014: 231) mendefinisikan bahwa wawancara (interview) merupakan pertemuan dua orang untuk bertukar informasi dan ide melalui tanya jawab, sehingga dapat menghasilkan makna yang terperinci dalam topik tertentu. Wawancara yang digunakan peneliti adalah wawancara semi terstruktur (semi structure interview). Wawancara ini dilakukan kepada pemilik atau karyawan UMKM dan konsumen yang datang ke UMKM yang berada di Bogor.

\section{Observasi}

Observasi merupakan kegiatan pengumpulan data melalui pengamatan atas gejala, fenomena dan fakta empiris yang terkait dengan masalah penelitian (Musfiqon, 2012: 120). Observasi yang digunakan oleh peneliti adalah metode observasi non partisipan. Pada observasi ini, peneliti tidak terlibat langsung dalam kehidupan orang-orang yang akan diobservasi, melainkan hanya mengamati proses kegiatan usaha UMKM yang dijalankan oleh para entrepreneur.

\section{Dokumentasi}

Dokumentasi merupakan catatan peristiwa yang telah berlalu. Dokumentasi bisa berbentuk tulisan, gambar, atau karyakarya monumental dari seseorang. Dalam penelitian ini teknik pengumpulan data dengan dokumentasi diperoleh dari fotofoto pribadi dan tulisan-tulisan yang berkaitan dengan UMKM.

\section{Validitas, Reliabilitas dan Objektivitas}

Dalam penelitian kualitatif, validitas internal disebut sebagai Kredibilitas (credibility) dan validitas eksternal disebut sebagai Keteralihan (transferability). Kredibilitas/validitas internal yang digunakan dalam penelitian ini adalah dengan menggunakan peningkatan ketekunan, triangulasi sumber data, bahan referensi dan mengadakan member check. Sedangkan, Keteralihan/validitas eksternal dalam penelitian ini adalah berkenaan dengan pertanyaan penelitian sehingga hasil penelitian dapat diterapkan dan digunakan dalam situasi yang lain.

Reliabilitas disebut sebagai dependability. Suatu data dikatakan reliabel apabila orang lain dapat mengulangi atau mereplikasi proses penelitian tersebut dan dilakukan dengan melakukan audit terhadap keseluruhan proses penelitian. 
objektivitas disebut sebagai uji confirmability. Suatu penelitian dinyatakan objektif apabila hasil penelitian telah disepakati banyak orang. uji confirmability mirip dengan uji dependability sehingga pengujiannya dapat dilakukan secara bersamaan.

\section{Teknik Analisis Data}

Analisis data yang digunakan adalah fenomenologi. Menurut Cresswell (1998) fenomenologi menjelaskan fenomena dan maknanya bagi individu dengan melakukan wawancara pada sejumlah individu. Selanjutnya dihubungkan dengan prinsipprinsip filosofis fenomenologi dan studi ini diakhiri dengan esensi dari makna. Berikut ini adalah tahapan penelitian analisis data fenomenologi menurut Colaizzi:

1. Peneliti mendeskripsikan sepenuhnya fenomena yang dialami subjek penelitian. Seluruh rekaman hasil wawancara mendalam dengan subjek penelitian ditranskripsikan ke dalam bahasa tulisan.

2. Tahap Horizonalization, yaitu tahap melengkapi data dari berbagai sumber. Selanjutnya, dari hasil transkripsi, peneliti menginventarisasi pernyataanpernyataan penting yang relevan dengan topik.

3. Tahap cluster of meaning: selanjutnya peneliti mengklasifikasikan pernyataanpernyataan tadi ke dalam tema-tema atau unit-unit makna. Pada tahap ini dilakukan:

a. Textural description (deskripsi tekstural): peneliti menulis apa yang dialami, yakni deskripsi tentang apa yang dialami individu.

b. Structural description (deskrispsi struktural): penulis menuliskan bagaimana fenomena itu dialami oleh para individu. Peneliti juga mencari makna berdasarkan peneliti sendiri, berupa opini, penilaian, perasaan, harapan subjek penelitian tentang fenomena yang dialaminya.

4. Tahap deskripsi esensi: peneliti mengonstruksi (membangun) deskripsi menyeluruh mengenai makna dan esensi pengalaman para subjek.

5. Peneliti melaporkan hasil penelitiannya.

\section{HASIL DAN PEMBAHASAN}

\section{Kegiatan UMKM}

\section{Usaha Bakso Raos (Usaha Mikro)}

Usaha bakso yang dirintis oleh Bapak Wawan yang berada di Jalan Surya Kencana Bogor telah berjalan sejak tahun 2006 hingga sekarang dengan tiga ruko yang dimiliki olehnya saat ini. Diantaranya berada di surya kencana, jalan milano dan kampus kesatuan. Kegiatan usahanya meliputi proses produksi pembuatan bakso dan pemasaran yang dilakukan oleh karyawannya setiap hari yang dimulai pukul 06.00-22.00 WIB. Karyawan yang dipekerjakan olehnya saat ini berjumlah kurang dari 10 orang.

Proses pembuatan bakso yang dijual di tempat ini merupakan bakso hasil buatan sendiri, berdasarkan hasil observasi peneliti ketika melihat proses produksi, daging yang dipakai untuk olahannya merupakan daging sapi yang dicincang langsung di pasar dan bahan lainnya juga diperoleh dari pasar. Setiap hari kegiatan produksi untuk membuat bakso mencapai 8-15 kg dengan pencapaian penjualan ratarata sebanyak $150-200$ porsi. Dari penjualan tersebut menghasilkan pendapatan kotor rata-rata sebesar Rp.3.000.000,- perhari pada satu tempat usahanya. 


\section{Usaha My Healthy Yoghurt (Usaha Kecil)}

Usaha yang dirintis oleh Ibu Sualwiyah dan Bapak Joko dimulai sejak tahun 2009 yang bertempat di Jalan Kp, Sawah Hilir No. 41 Mekarjaya Ciomas Bogor. Usaha ini bergerak di bidang minuman yaitu yoghurt, produk yang diminati semua konsumen khususnya anak sekolah. Sehingga target dari usaha ini adalah kantin sekolah dan warung-warung. Pada awal pembukaan usaha, konsumen yang menjadi target adalah kantin dan warung tetapi seiring dengan perkembangan saat ini konsumen yang dilayani adalah agen dengan pembelian dalam jumlah yang besar. Produk yoghurt ini juga telah didukung dengan adanya label halal yang disahkan oleh MUI pada tahun 2016 telah diperbaharui kehalalannya. Pada saat ini karyawan yang dimilikinya sudah berjumlah 39 karyawan yang terdiri dari 33 karyawan lepas dan 6 karyawan tetap. Kegiatan karyawan dimulai pukul 07.3022.00 WIB, namun waktu tersebut bisa saja lebih cepat untuk karyawan menyelesaikan pekerjaannya tergantung banyaknya pemesanan yoghurt pada saat itu.

Proses produksi pembuatan yoghurt dimulai dari memasukan susu murni yang berasal dari salah satu koperasi yang menjual susu murni dan bahan lainnya seperti bakteri untuk dilakukan fermentasi. Berdasarkan hasil observasi susu yang digunakan adalah susu yang murni dan tidak mengandung zat yang berbahaya. Hal tersebut juga dikuatkan dengan adanya label MUI dimana pihak MUI juga telah mengecek kehalalan dari bahan yang dipakai untuk pembuatan produk. Setiap hari karyawan dapat memproduksi yoghurt sebanyak 500-1500 liter. Produk ini akan dibuat dalam bentuk stick dan botol, tetapi yang paling banyak dibuat saat ini adalah produk yoghurt berbentuk stick yang akan ditujukan kepada anak-anak sekolah. Stick yoghurt dijual ke agen dengan harga $\mathrm{Rp}$. 12.000,- dan yoghurt dengan kemasan botol dijual seharga Rp. 5.000,--

\section{Usaha Ayam (Usaha Menengah)}

Usaha ayam ini merupakan usaha yang dimiliki oleh Bapak H.Gandi yang terletak di Pasar Cisarua Jalan Raya Puncak Cisarua Bogor yang telah dibuka selama dua tahun ini. Sebelumnya penjualan ayamnya tidak dilakukan di pasar dan telah menggeluti usaha ayam sejak tahun 1985 sebagai pemotong ayam besar namun kini berpindah sebagai penjual ayam di pasar. Partisipan saat ini hanya memperkerjakan dua orang karyawan yang dimulai pukul 06.00-18.00 WIB.

Setiap hari partisipan memesan ayam dari pemotong yang berada di Cipanas dengan pernyataan yang menyatakan bahwa ayam yang dijualnya adalah ayam yang dipotong sesuai dengan syariat Islam. Ayam yang dipesan mencapai 80-1 kwintal tetapi pada hari libur pemesanan bisa mencapai 2 kwintal. rata-rata perolehan dari penjualan tersebut mencapai $90 \mathrm{~kg}$ dengan pendapatan kotor perhari sebesar Rp.3.000.000,-.

\section{Karakteristik Entrepreneur Syariah pada UMKM}

\section{Usaha Bakso Raos (Usaha Mikro)}

Jujur

Rasulallah SAW menganjurkan kejujuran dalam bermuamalah dan senantiasa memiliki sifat benar (shiddiq) (Nurcholifah: 2015: 14; Markas: 2014: 171). Oleh karena itu peran kejujuran dalam jual beli sangat penting. Allah SWT berfirman dalam Q.S Al-Ahzab: 70 berikut ini. 


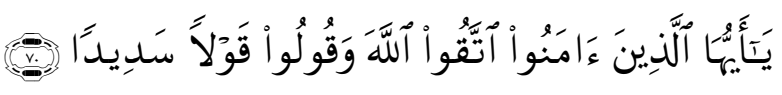

Artinya: Hai orang-orang yang beriman, bertakwalah kamu kepada Allah dan Katakanlah Perkataan yang benar.

Karakteristik entrepreuner salah satunya adalah kejujuran, dalam penelitian ini indikator kejujuran yang diamati adalah transparansi bahan dan harga.

Berdasarkan indikator transparansi bahan baku produksi, hasil penelitian menunjukkan bahwa partisipan berkata benar tentang pembuatan produksinya dan sesuai dengan hasil observasi ketika pembuatan bakso raos dan tidak ditemukan adanya penggunaan bahan pengawet hanya pembuatannya yang tidak memakai sarung tangan sehingga kurang steril.

Sementara itu, berdasarkan indikator transparansi harga produk adalah partisipan tidak menyertakan harga perolehan ketika melakukan transaksi jualbeli dan sesuai dengan pernyataan konsumen bahwa harga dan pelayanan yang diberikan sesuai dan dapat memuaskan pelanggan. Sebagaimana sebuah bisnis harus dibangun atas dasar keterbukaan antara kedua belah pihak yaitu penjual dan konsumen serta tidak ada konsumen yang dirugikan (Nawatmi, 2010: 55).

\section{Bisnis secara adil atau keadilan}

Variabel kedua yang terkait dengan karakteristik entrepreuner syariah adalah keadilan. Indikator keadlilan dilihat dari tiga indikator yaitu persamaan perlakuan konsumen, perlakuan terhadap karyawan dan takaran produk.

Dilihat dari indikator persamaan perlakuan konsumen menunjukkan bahwa partisipan memperlakukan konsumen dengan pelayanan yang sama begitupun kepada karyawan. Hal tersebut juga dikuatkan oleh pernyataan dari dua konsumen yang menyatakan bahwa merasa puas dengan pelayanan yang diberikan sehingga membuatnya mendatangi tempat ini dan membeli produk usaha ini. Sebagaimana dalam Islam, mengorientasikan manusia untuk bersikap seimbang dan adil dalam konteks hubungan baik dengan diri sendiri maupun dengan orang lain begitupun dalam kegiatan bisnis, setiap konsumen berhak mendapatkan pelayanan yang benar (Yusri: 2009: 367).

Berdasarkan indikator perlakuan terhadap karyawan, menunjukkan bahwa setiap karyawan melakukan pekerjaan dan pemberian upah sesuai dengan tanggung jawabnya. Sebagaimana dalam Islam, upah diberikan sesuai dengan tenaga kerjanya dalam melaksanakan kegiatan produksi (Koentjoro: 2011: 11).

Indikator takaran produk dapat dilihat penjual membuat bakso tanpa menggunakan alat takaran tetapi hanya menggunakan takaran didasarkan pada keinginan sendiri yang disesuaikan dengan harga jual. Sebagaimana seorang entrepreneur harus seimbang dan adil tidak berlebihan dan tidak mengejar keuntungan semata salah satunya yaitu sempurna dalam timbangan menurut Imam Ibnu Taimiyah (nawatmi, 2010: 54).

\section{Komunikatif atau cakap}

Komunikasi atau kecakapan merupakan variabel selanjtnya, yang turunannya terdiri dari indikator penyampaian perintah, penyelesaian pekerjaan dan komunikasi kepada konsumen. Indikator penyampaian perintah kepada karyawan adalah adanya bentuk pegarahan yang dilakukan kepada 
karyawan dengan harapan dapat memberikan kedisiplinan dan mencapai tujuan usaha. Sebagaimana seorang entrepreneur harus memiliki jiwa kepemimpinan, mampu menyampaikan dan mengarahkan karyawannya demi tujuan usaha yang akan dicapai (Sakdiah, 2016: 31-32).

Hasil analisis terhadap indikator penyelesaian pekerjaan menunjukkan bahwa partisipan melakukan musyawarah ketika ada salah satu karyawannya membuat kesalahan dan akan dilakukan pengarahan tidak hanya bagi yang melakukan kesalahan tetapi untuk semua karyawannya. Selain itu, hasil observasi menunjukkan bahwa partisipan mengedepankan pelayanan dan penjualannya agar konsumen merasa puas dengan bakso dan pelayanannya. Sebagaimana sikap seorang entrepreneur yang tidak hanya pandai berkomunikasi kepada karyawan tetapi juga kepada konsumennya dan mampu memberikan berbagai macam promosi untuk melayani konsumennya merasa nyaman dengan produk yang ditawarkan (Cahyani, 2015: 215).

Berdasarkan analisa terhadap indikator komunikasi kepada konsumen menunjukkan bahwa partisipan melakukan teknik penjualan dan sesuai dengan hasil observasi. Sebagaimana seorang entrepreneur harus berkomunikasi kepada konsumen salah satunya yaitu dengan bersikap ramah agar memberikan kepuasan kepada konsumen.

\section{Senang membantu pelanggan}

Berdasarkan indikator membantu kesulitan pelanggan, menunjukkan bahwa partisipan tidak membantu konsumen secara langsung tetapi menemukan keadaan ketika konsumen yang tidak mampu membayar dengan motifnya telah melakukan pembayaran. Selain hal tersersebut, ditemukan juga adanya keluhan yang berasal dari konsumen ketika pemesanan lama sehingga membuat konsumen membatalkan pemesanannya. Hal tersebut sesuai dengan hasil wawancara dan observasi yang dilakukan oleh peneliti kepada dua konsumen yang mengunjungi tempat usaha ini. Pada dasarnya, berbisnis tidak hanya untuk mencari keuntungan semata tetapi untuk memberikan kemudahan bagi orang lain dengan menjual barang (Nawatmi, 2010: 55).

Indikator menyiapkan kebutuhan konsumen menunjukkan bahwa adanya kesiapan karyawan untuk menyiapkan kebutuhan dan bertanggung jawab terhadap keluhan konsumen. Hal tersebut sesuai dengan hasil wawancara yang ditujukkan kepada dua konsumen yang menyatakan bahwa adanya sikap permintaan maaf ketika pemesanannya mengalami keterlambatan dan menyiapkan secara cepat ketika menemukan konsumen membutuhkan bantuan ketika dalam pemesanan. Sebagaimana seorang entrepreneur hendaknya menyadari bahwa pentingnya saling membantu dalam kegiatan usaha sehingga diperlukan integritas tinggi pada konsumen agar merasa dibantu dan merasa puas dengan pelayanan yang diberikan (Nawatmi, 2010: 57).

\section{Menjaga hak-hak konsumen}

Variabel selajutnya menganalisis tentang hak-hak konsumen. Hasil penelitian menunjukkan bahwa partisipan menepati janji kepada konsumen dalam hal ini adalah pelayanan yang diberikan. Hal tersebut dikuatkan dengan observasi yang peneliti lakukan dan hasil wawancara 
kepada dua konsumen yang mengunjungi tempat usaha ini, keduanya menyatakan bahwa pemesanan dikirim tepat waktu terkecuali sedang ramai dan konsumen dapat memaklumi hal tersebut terkecuali ada pembeli yang tidak dapat memakluminya dan memutuskan untuk membatalkan pemesanannya. Sebagaimana dilakukan oleh Rasulallah SAW dalam menjalankan kegiatan usahanya yaitu selalu menyerahkan barang-barang pesanan sesuai dengan waktu yang telah ditentukan (Nawatmi, 2010: 57).

Berdasarkan indikator hak pembatalan pembelian (hak khiyar), menunjukkan bahwa membolehkan pembeli melakukan pembatalan pada saat itu juga atau dalam Islam disebut sebagai hak khiyar majlis yaitu hak yang diberikan kepada konsumen untuk melakukan pembatalan atau melangsungkan pembelian pada saat itu juga selama mereka masih berada di lokasi kontrak (Huda, 2013: 9).

\section{Menunaikan zakat, infaq dan shadaqah}

Partisipan mengeluarkan zakatnya setiap tahun dengan perolehan pendapatan rata-rata perhari mencapai Rp.2.500.000Rp.3.000.000,-. Menunaikan zakat, infaq dan shadaqah harus menjadi budaya bagi entrepreneur syariah (Zahroh, 2014: 112116). sebagaimana Firman Allah SWT dalam Surat At-Taubah: 10 berikut ini.
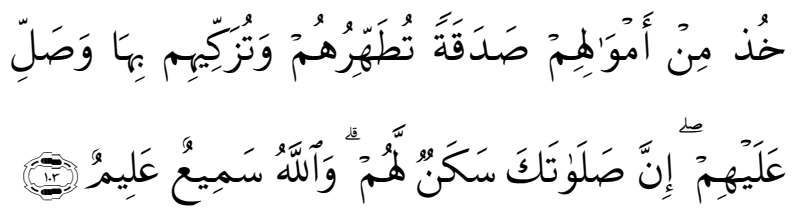

Artinya: Ambillah zakat dari sebagian harta mereka, dengan zakat itu kamu membersihkan[658] dan mensucikan[659] mereka dan mendoalah untuk mereka. Sesungguhnya doa kamu itu (menjadi) ketenteraman jiwa bagi mereka. dan Allah Maha mendengar lagi Maha mengetahui.

\section{Usaha My Healthy Yoghurt (Usaha Kecil)}

Jujur

Berdasarkan indikator transparansi bahan baku produksi, menunjukkan bahwa proses produksi yang dijalankan sesuai dengan hasil observasi peneliti. Hal tersebut dikuatkan dengan adanya label MUI pada produk yoghurt yang telah diuji kehalalan bahan yang digunakan. Sebagaimana memproduksi suatu produk baik barang atau jasa, kehalalan dan kemaslahatan produk sangat diutamakan (Yusri: 2009: 336). Allah SWT berfirman dalam surat Al-Baqarah: 168 berikut ini.

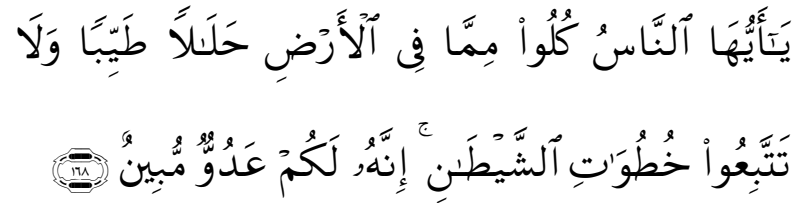

Artinya: Hai sekalian manusia, makanlah yang halal lagi baik dari apa yang terdapat di bumi, dan janganlah kamu mengikuti langkah-langkah syaitan; karena Sesungguhnya syaitan itu adalah musuh yang nyata bagimu.

Indikator transparansi harga produk menggambarkan partisipan tidak melakukan kegiatan jual beli dengan menyebutkan marginnya dan secara langsung menawarkan harga jualnya kepada agen. Sebagaimana dalam jual beli yang dilakukan oleh Nabi Muhammad SAW pada saat itu menyebutkan keuntungannya atau nilai margin dari barang yang dijual dan sekarang dikenal dengan akad murabahah (Alam: 2014: 27)

\section{Bisnis secara adil atau keadilan}

Indikator persamaan perlakuan konsumen menunjukkan bahwa partisipan memperlakukan dan melayani konsumen 
sama tidak ada yang dibedakan. Sebagaimana hasil wawancara yang dilakukan kepada dua konsumen yang telah menjadi pembeli yoghurt sejak dulu menyatakan bahwa sejak awal pembeliannya yang masih dalam jumlah sedikit sehingga banyak seperti sekarang masih mendapatkan pelayanan yang memuaskan. Dalam perspektif Islam, telah mengorientasikan manusia untuk bersikap seimbang dan adil dalam konteks hubungan baik dengan diri sendiri maupun dengan orang lain begitupun dalam kegiatan bisnis, setiap konsumen berhak mendapatkan pelayanan yang benar (Yusri: 2009: 367).

Berdasarkan indikator perlakuan terhadap karyawan, dapat dilihat bahwa karyawan diberikan upah sesuai dengan pendapatan pack yoghurt yang dihasilkan setiap harinya. Sebagaimana dalam Islam, pembagian upah tidak dibenarkan di bawah tingkat minimum yang ditetapkan berdasarkan kebutuhan dan tidak dibenarkan adanya kenaikan upah melebihi yang ditentukan terhadap produksi. Sehingga pemberian upah harus sesuai dengan tenaga kerja karyawan dalam melaksanakan kegiatan produksi (Koentjoro, 2011: 1).

Adapun untuk takaran produk, takaran tersebut telah disesuaikan dengan banyaknya stick yang ada pada setiap satu pack yoghurt. Setiap satu pack yoghurt berisi 30 stick dengan harga Rp.12.000 dengan isi $50 \mathrm{ml}$ per stick dan harga per sticknya adalah Rp.400 jika dijual ke agen dan agen bebas menjualnya kembali kepada reseller atau konsumen dengan harga berapapun Sebagaimana seorang entrepreneur syariah harus seimbang dan adil khususnya dalam penentuan harga dan takaran (Nawatmi, 2014: 54). Allah SWT berfirman dalam surat Al-Muthaffiffin: 1-3 berikut ini.

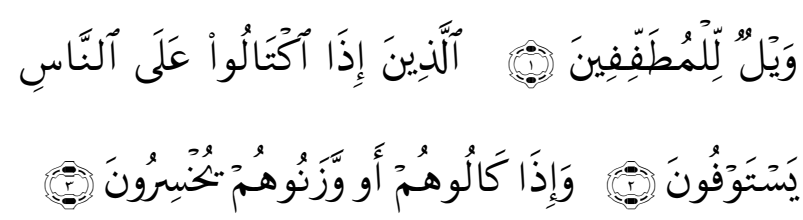

Artinya: kecelakaan besarlah bagi orangorang yang curang, (yaitu) orang-orang yang apabila menerima takaran dari orang lain mereka minta dipenuhi, dan apabila mereka menakar atau menimbang untuk orang lain, mereka mengurangi.

\section{Komunikatif atau cakap}

Indikator penyampaian perintah kepada karyawan adalah adanya kegiatan briefing yang dilakukan setiap hari jumat sebagai bahan evaluasi dan jika ada komplain dari konsumen atau agen. Hasil penelitian yang dilakukan menunjukkan bahwa terdapat karakter kepemimpinan dalam diri pengawas yang ditugaskan oleh partisipan untuk mengatur karyawan. Hal tersebut sesuai dnegan observasi yang dilakukan oleh peneliti. Sebagaimana karakter kepemimpinan dalam berkomunikasi kepada karyawan yaitu mampu menggerakan, mengajak dan mengarahkan karyawan agar bekerja sesuai dengan tujuan yang akan dicapai (Sakdiah, 2016: 31-32).

Indikator penyelesaian pekerjaan menunjukkan bahwa partisipan berusaha mengatasi setiap ada masalah salah satunya pada konsumen yang meminta pengiriman secara cepat. Oleh karena itu, partisipan membuat beberapa persyaratan ketika akan melakukan pemesanan. Seorang entrepreneur dalam memimpin sebuah usahanya harus mampu mengkoordinasi relasi atau konsumennya agar tercipta suatu keberhasilan usaha (Sakdiah: 2016: 31-32). 
Indikator komunikasi kepada konsumen menunjukkan bahwa Partisipan menyampaikan promosinya melalu media sosial seperti melalu website yang sudah tersedia.

\section{Senang membantu pelanggan}

Berdasarkan indikator membantu kesulitan pelanggan, dapat dilihat bahwa partisipan membantu pemasaran atau memudahkan agen untuk menjual produk yoghurt. Sehingga selain meningkatkan keuntungan untuk usahanya juga membantu untuk meningkatkan keuntungan setiap agen. Hal tersebut dibenarkan oleh pernyataan dari dua konsumen yang telah diwawancarai oleh peneliti yang menyebutkan bahwa adanya bantuan promosi untuk agen. Sebagaimana seorang entrepreneur syariah hendaknya memiliki kesadaran tentang pentingnya saling membantu dalam kegiatan usaha juga dalam kegiata sosial (Nawatmi, 2010: 57).

Indikator menyiapkan kebutuhan konsumen menunjukkan bahwa terhadap usaha ini partisipan mengutamakan pelayanan dan membantu pelanggan bagaimanapun kondisi dan karakter konsumen. Sebagaimana Rasulallah SAW dalam menjalankan kegiatan usahanya yaitu memiliki rasa tanggung jawab yang besar dan integritas yang tinggi pada konsumennya agar merasa terbantu dan merasa puas dengan pelayanan yang diberikan (Nawatmi, 2010: 57).

\section{Menjaga hak-hak konsumen}

Peneliti menganalisa bahwa partisipan menepati janji kepada konsumen dalam hal ini adalah partisipan melakukan promosi melalui media sosial dan website sehingga setiap pesanan akan ditanggapi melalui pesan singkat, telepon atau pesan dari media sosial dan akan dikirim sesuai penjadwalan terkecuali konsumen meminta lebih cepat untuk dikirimkan. Berdasarkan hasil wawancara kepada dua konsumen menyatakan bahwa hasil wawancara dengan pemilik usaha sesuai dengan menyatakan pemesanan dikirim sesuai dengan jadwal yang telah ditentukan. Sebagaimana yang dilakukan oleh Rasulallah SAW dalam menajalankan kegiatan usahanya selalu menyerahkan barang-barang pesanan sesuai dengan waktu yang telah ditentukan (Nawatmi, 2010: 57).

Berdasarkan indikator hak pembatalan pembelian (hak khiyar), menunjukkan bahwa ada pemberian hak pembatalan yaitu pembatalan dengan jangka waktu dua hari. Dalam Islam, disebutkan bahwa jika menemukan pembatalan terhadap produk yang dibeli dengan mensyaratkan waktu disebut sebagai hak khiyar syarat (Huda, 2013: 9).

\section{Menunaikan zakat, infaq dan shadaqah}

Untuk aktivitas terkait dengan kewajiban dalam menunaikan zakat, infak dan shadaqah menunjukkan bahwa partisipan telah mengeluarkan zakatnya setiap tahun dengan pendapatan kotor rata-rata perbulan mencapai Rp.70.000.000. alokasi dana zakatnya diberikan kepada rumah yatim yang didirikan oleh pemilik usaha. sebagaimana Firman Allah SWT dalam Surat At-Taubah: 10 berikut ini.

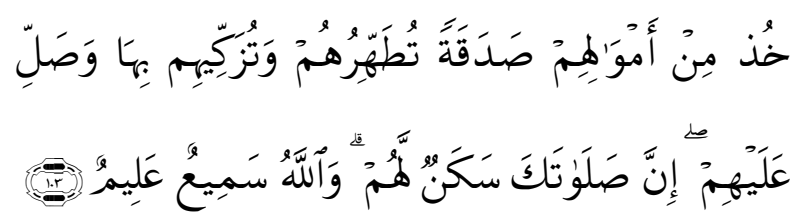

Artinya: Ambillah zakat dari sebagian harta mereka, dengan zakat itu kamu membersihkan[658] dan mensucikan[659] mereka dan mendoalah untuk mereka. Sesungguhnya doa kamu itu (menjadi) 
ketenteraman jiwa bagi mereka. dan Allah Maha mendengar lagi Maha mengetahui.

\section{Usaha Ayam (Usaha Menengah) Jujur}

Berdasarkan indikator transparansi bahan baku produksi, menunjukkan bahwa partisipan menjual ayam yang segar dan telah menyatakan bahwa ayam yang dijualnya adalah ayam yang dipotong sesuai dengan syariat Islam. Sebagaimana dalam Islam, Rasulallah dalam melakukan kegiatan bisnis menganjurkan untuk memiliki sifat benar atau jujur (shiddiq) (Nurcholifah: 2015: 14). Allah SWT berfirman dalam Alqur'an surat Al-Ahzab: 70 berikut ini.

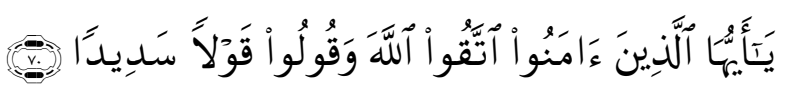

Artinya: Hai orang-orang yang beriman, bertakwalah kamu kepada Allah dan Katakanlah Perkataan yang benar.

Indikator transparansi harga produk menggambarkan partisipan tidak menyertakan harga perolehan kepada konsumen tetapi harga ayam akan disesuaikan dengan keadan ayam. Sebagaimana konsep keadilan dalam harga jual yaitu kualitas yang setara dan harga juga setara (Alam: 2014: 27).

\section{Bisnis secara adil atau keadilan}

Indikator persamaan perlakuan konsumen menunjukkan bahwa harga jual ayam diberikan sama kepada semua konsumen dan akan dilakukan penurunan harga jika dalam pembelian dalam jumlah banyak. Hal tersebut dikuatkan oleh pernyataan dari dua konsumen dan observasi penulis yang menyatakan harga jual yang diberikan sesuai dengan harga jual lainnya. Sebagaimana firman Allah dalam surat Al-Maidah: 8 yang menjelaskan bahwa seorang entrepreneur syariah perlu menegakan keadilan dalam kegiatan bisnis khususnya keadilan bagi konsumen. Seorang entrepreneur hendaknya tidak boleh membedakan dan memberikan tingkat kepuasan yang seimbang kepada konsumen (Zaroni, 2007: 180).

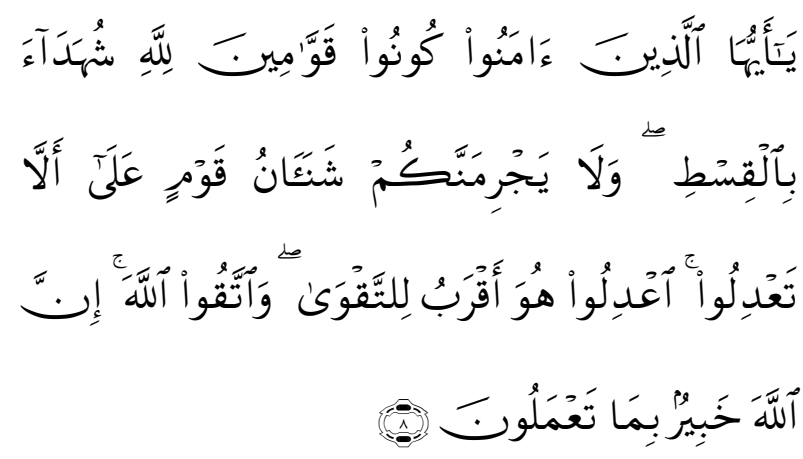

Artinya: "Hai orang-orang yang beriman hendaklah kamu Jadi orang-orang yang selalu menegakkan (kebenaran) karena Allah, menjadi saksi dengan adil. dan janganlah sekali-kali kebencianmu terhadap sesuatu kaum, mendorong kamu untuk Berlaku tidak adil. Berlaku adillah, karena adil itu lebih dekat kepada takwa. dan bertakwalah kepada Allah, Sesungguhnya Allah Maha mengetahui apa yang kamu kerjakan".

Berdasarkan indikator perlakuan terhadap karyawan, dapat dijelaskan bahwa upah yang diberikan sesuai dengan jam kerja yang diberlakukan kepada karyawannya. Sebagaimana dalam Islam, pemberian upah harus sesuai dengan tenaga kerja karyawan dalam melaksanakan kegiatan produksi (Koentjoro, 2011: 1).

Berdasarkan takaran produk dapat dilihat kesesuaian dengan hasil observasi penulis bahwa alat takar yang digunakan untuk menimbang ayamnya masih menggunakan timbangan berwarna kuning emas atau barang tradisional belum memakai mesin. Oleh karena itu, membuat beberapa konsumen ingin melihat dan mengeceknya di toko lain. Dalam kegiatan 
bisnis, timbangan harus disempurnakan, karena jika terdapat pengurangan hak atas suatu barang akan menimbulkan tindak kedzaliman (nawatmi, 2010: 54). Allah SWT berfirman dalam surat Al-Muthaffifin: 1-3 berikut ini.

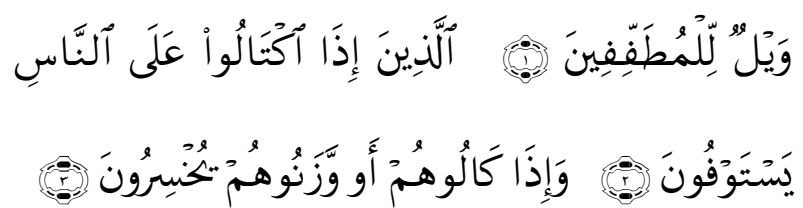

Artinya: kecelakaan besarlah bagi orangorang yang curang, (yaitu) orang-orang yang apabila menerima takaran dari orang lain mereka minta dipenuhi, dan apabila mereka menakar atau menimbang untuk orang lain, mereka mengurangi.

\section{Komunikatif atau cakap}

Indikator penyampaian perintah kepada karyawan adalah partisipan memiliki sikap yang tegas dalam melakukan pengarahan kepada karyawan, sehingga setiap hari akan ada pengarahan kepada karyawan agar pelayanan penjualannya dapat memberikan kepuasan. Hal tersebut sesuai dengan observasi yang dilakukan oleh peneliti. Sebagaimana karakter kepemimpinan dalam berkomunikasi kepada karyawan yaitu mampu menggerakan, mengajak dan mengarahkan karyawan agar bekerja sesuai dengan tujuan yang akan dicapai (Sakdiah, 2016: 31-32).

Indikator penyelesaian pekerjaan menunjukkan bahwa partisipan tidak melakukan musyawarah terlebih dahulu tetapi langsung memberikan pengarahan secara langsung. Selain itu, partisipan memiliki beberapa strategi untuk mempertahankan pelanggannya dengan memberikan diskon kepada konsumennya agar tetap loyal. Sebagaimana dalam kegiatan usaha, seorang entrepreneur harus memiliki jiwa kepemimpinan yang mampu mengarahkan dan memberikan toleransi kepada konsumen (Sakdiah: 2016: 31-32).

Berdasarkan hasil penelitian untuk indikator komunikasi kepada konsumen menunjukkan bahwa partisipan melakukan teknik promosi dengan mengeraskan suara ketika menawarkan ayamnya. Hal tersebut sesuai dengan hasil observasi. Sebagaimana seorang entrepreneur harus memiliki sikap yang ramah ketika melayani konsumen.

\section{Senang membantu pelanggan}

Berdasarkan indikator membantu kesulitan pelanggan, peneliti menganalisa bahwa partisipan memberikan keringanan berupa penurunan harga kepada konsumen dengan pembelian dalam jumlah banyak. Sehingga tidak ada bentuk keringanan yang diberikan secara cuma-cuma kepada konsumen. Selain itu, beberapa keluhan dari konsumen yaitu ayam kurang bagus dan pemotongan ayam yang tidak sesuai. Tetapi partisipan akan menggantinya langsung sesuai permintaan konsumen. Sebagaimana hasil wawancara kepada dua konsumen yang hendak membeli menyatakan bahwa ayam yang dijual bagus dan besar tetapi sebagian konsumen mengeluhkan potongan ayamnya belum sesuai. Sebagaimana seorang entrepreneur syariah hendaknya memiliki kesadaran tentang pentingnya saling membantu dalam kegiatan usaha juga dalam kegiata sosial (Nawatmi, 2010: 57).

Indikator menyiapkan kebutuhan konsumen menunjukkan bahwa partisipan belum memiliki ahli dalam memotong sehingga mendapatkan beberapa keluhan dari konsumen. Hal tersebut dikuatkan oleh pernyataan konsumen. Sebagaimana Rasulallah SAW dalam menjalankan kegiatan usahanya yaitu memiliki rasa tanggung jawab yang besar dan integritas 
tinggi pada konsumennya agar merasa terbantu dan merasa puas dengan pelayanan yang diberikan (Nawatmi, 2010: 57).

\section{Menjaga hak-hak konsumen}

Untuk Indikator ketepatan janji kepada konsumen dalam hal ini adalah partisipan melakukan penjualan secara langsung dengan konsumen di pasar sehingga berkomunikasi dan melayaninya sesuai permintaan. Sedangkan, pesanan yang dikirim ke restoran akan diantar sesuai permintaan konsumen. Sebagaimana yang dilakukan oleh Rasulallah SAW dalam menajalankan kegiatan usahanya selalu menyerahkan barang-barang pesanan sesuai dengan waktu yang telah ditentukan (Nawatmi, 2010: 57).

Berdasarkan indikator hak pembatalan pembelian (hak khiyar), analisa peneliti menunjukkan bahwa partisipan pernah mengalami pembatalan pembelian dari pemesan dan meminta diganti karena diketahui terdapat kecacatan pada barang yang diterimanya. Hal tersebut dapat disebut sebagai khiyar ru'yah yaitu adalah hak untuk membatalkan atau melanjutkan pembelian karena ketika akad berlangsung tidak ada ditempat barangnya. Namun, pada konteks ini konsumen meminta untuk diganti dengan yang baru ayamnya ketika mengetahui pesanan ayam tidak sesuai (Huda. 2013: 9).

\section{Menunaikan zakat, infaq dan shadaqah}

Analisa peneliti menunjukkan bahwa partisipan belum mengeluarkan zakat pada tahun ini dikarenakan dari pendapatan yang diperoleh belum memenuhi untuk wajib zakat, sehingga partisipan menngeluarkan infaqnya setiap bulan sebesar Rp.250.000,-. Sebagaimana Firman Allah SWT dalam Surat At-Taubah: 10 berikut ini.

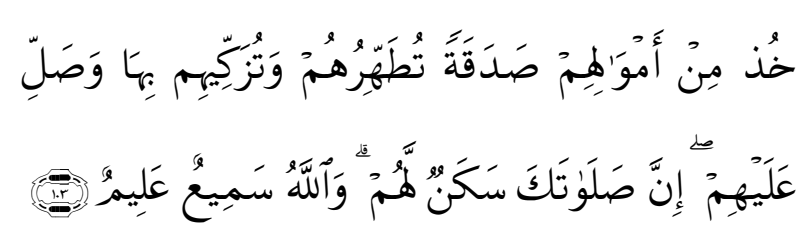

Artinya: Ambillah zakat dari sebagian harta mereka, dengan zakat itu kamu membersihkan[658] dan mensucikan[659] mereka dan mendoalah untuk mereka. Sesungguhnya doa kamu itu (menjadi) ketenteraman jiwa bagi mereka. dan Allah Maha mendengar lagi Maha mengetahui.

\section{Dampak Penerapan Karakteristik Entrepreneur Syariah pada UMKM}

\section{Usaha Bakso Raos (Usaha Mikro)}

Dampak usaha dari adanya karakteristik yang dimiliki mengalami peningkatan pertama mulai dari produksi yang saat ini sudah mencapai 8-12 kg perharinya. Kedua, peningkatan dari penjualan yang mencapai rata-rata 150 mangkuk pada satu tempat dan dua tempat lainnya. Ketiga, dari hasil penjualan tersebut meningkatkan pendapatan usaha bakso ini yang mencapai Rp.3.000.000 setiap hari dan terakhir peningkatan yang terlihat pada luasnya pasar dimana usaha bakso yang telah didirikan di tiga tempat yang berbeda.

\section{Usaha My Healthy Yoghurt (Usaha Kecil)}

Sebagiamana hasil wawancara yang dilakukan menunjukan dampak usaha dari penerapan karakteristik entrepreneur syariah yaitu pertama dilihat dari peningkatan produksi, awalnya produksi hanya sebanyak 50 liter tetapi saat ini sudah mencapai 500-1500 liter setiap hari. Kedua, peningkatan penjualan terlihat pada target konsumennya yaitu agen-agen besar berbeda dengan awal pembukaan usaha yang hanya menawarkan produk yoghurt ke warung-warung kecil. Ketiga, peningkatan penjualan tersebut juga 
meningkatkan pendapatan yang telah mencapai 1300 pack setiap hari yang dipesan oleh konsumen dengan pendapatan kotor Rp.70.000.000 perbulan dan terakhir luasnya pasar yang dikuasai saat ini yang juga memanfaatkan teknologi sebagai sarana pemasaran.

\section{Usaha Ayam (Usaha Menengah)}

Dampak usaha dari penerapan karakteristik entrepereneur syariah menunjukkan bahwa mengalami beberapa peningkatan dan penurunan. Pertama, pencapaian produksi sebagai pemotong mengalalami penurunan sehingga partisipan memutuskan menjual ayam dipasar dengan persediaan 80-1 kwintal setiap hari. Kedua, penjualan rata-rata dari persediaan memperoleh $90 \mathrm{~kg}$ ayam yang berhasil dijual. Ketiga, pendapatan dari hasil penjualan perhari dapat diperoleh rata-rata sebesar Rp.3.000.000,- dan terakhir konsumen yang menjadi target pasrtisipan adalah restoran dan konsumen asing yang berada di wilayah Cisarua.

\section{KESIMPULAN DAN IMPLIKASI}

Penelitian yang dilaksanakan pada tiga tempat usaha UMKM di Bogor yaitu usaha bakso raos, usaha my healthy yoghurt dan usaha ayam mengenai karakteristik entrepreneur syariah pada UMKM menghasilkan beberapa kesimpulan sebagai berikut:

1. Kegiatan praktik usaha bakso raos bergerak di bidang makanan dan berlangsung setiap hari. Berbeda dengan usaha my healthy yoghurt yang bergerak di bidang minuman yaitu melakukan produksi dan penjualan yoghurt yang berlangsung setiap hari senin-sabtu dengan 39 karyawan.
Selain itu, usaha yang ketiga adalah usaha ayam yang bergerak di bidang penjualan ayam dengan menawarkan ayam segar setiap hari kepada konsumen dan restoran di Cisarua.

2. Ketiga usaha UMKM ini telah memiliki karakteristik entrepreneur syariah tetapi terdapat beberapa karakter yang belum memenuhi seperti usaha bakso raos yang belum menjaga kebersihan dalam proses produksi dan mengecek kehalalan daging yang dibeli. Usaha ayam yang belum memenuhi hak konsumen untuk mendapatkan produk sesuai pesanan.

3. Dampak usaha dari adanya penerapan karakteristik entrepreneur syariah ini menunjukkan peningkatan pada ketiga usaha UMKM ini mulai dari peningkatan produksi, penjualan, pendapatan dan luasnya promosi dan pasar.

\section{DAFTAR PUSTAKA}

Abdullah, M. Ma'ruf. 2013. Wirausaha Berbasis Syariah. Banjarmasin: Aswaja Pressindo Cetakan pertama.

Alam. A. I. A. 2014. Analisis Harga Jual Produk Berbasis Nilai keadilan pada Lembaga Usaha Berlabel Syariah (Studi Kasus pada Unit Usaha Pesantren Modern Immim Putra Makassar). Skripsi. Universitas Hasanuddin Makassar.

Alim, N. 2009. Pembiayaan Syariah Untuk Usaha Mikro dan Kecil: Studi Kasus dan Solus, cet. I. Surabaya: PT. Bina Ilmu.

Amalia, F. 2014. Etika Bisnis Islam: Konsep dan Implementasi Pada Pelaku 
Usaha Kecil. Jurnal Al-Iqtishad, Vol. VI No. 1. hal: 142

Antoni. 2014. Muslim Entrepreneurship: Membangun Muslimpreneurs Characteristics Dengan pendekatan Knowladge Based Economy. ELHIKAM: Jurnal Pendidikan dan Kajian KeIslaman, Volume VII Nomor 2. hal: 338.

Arikunto, Suharsimi. 2010. Prosedur Penelitian; Suatu Pendekatan Praktek. Jakarta: Rineka Cipta.

Cahyani, U. E. 2015. Pengembangan Jiwa Kewirausahaan Berbasis Syariah di IAIN PadangSidimpuan. Jurnal AtTijaroh, Vol 1 No 1. hal: 212

Desvianto, S. 2013. Studi Fenomenologi: Proses Pembentukan Persepsi Mantan Pasien di Rumah Pemulihan Soteria. Jurnal E-KOMUNIKASI, Vol. 1 No. 3.

Dominicus Savio Priyarsono, L. D. 2014. Pengaruh Karakter Wirausahawan terhadap Keberhasilan UMKM: Perspektif Islam. Jurnal Ekonomi Islam Republika.

Fajrina, Dyas Nur. 2015. Analisis Penerapan Bisnis Berbasis Syariah Pada Wirausaha Muslim (Study Pada Wirausaha Muslim di Perumahan Kaliwungu Indah-Kendal). Skripsi. Semarang: Fakultas Ekonomi Dan Bisnis Islamuniversitas Islam Negeri Walisongo.

Gabriela, Hawa. 2014. Analisis Karakteristik Wirausahwa Muslim Dalam Upaya Mencapai Kesuksesan Usaha (Studi Kasus di Sentra Industri Rambak Desa Penanggulangan Kecamatan Pegandon Kabupaten Kendal. Skripsi. Semarang: Fakultas
Ekonomi Bisnis Islam Universitas Isalam Negeri.

Hafidhuddin, D. 2003. Islam Aplikatif, Cet. pertama. Jakarta: Gema Insani.

Hasbiansyah, O. 2008. Pendekatan Fenomenologi: Pengantar Praktik Penelitian dalam Ilmu Sosial dan Komunikasi. Jurnal MEDIATOR, Vol. 9 No. 1. Hal 170

Huda, D. S. M. 2013. Tinjauan Hukum Islam Terhadap penerapan Khiyar dalam Jual Beli Barang Elektronik Secara Online (Studi Kasus di toko Online Kamera Mbantul). Skripsi. Universitas Islam Negeri Sunan Kalijaga.

Jasafat. 2015. Manajemen Pengelolaan Zakat, Infaq Dan Sadaqah Pada Baitul Mal Aceh Besar. Jurnal Al Ijtimaiyyah, Vol: 1 No: 1 . Hal 1

Kara, M. 2013. Kontribusi Pembiayaan Perbankan Syariah Terhadap Pengembangan UMKM di Kota Makasar. Jurnal Ilmu Syariah dan Hukum, Volume 47. hal: 269, 272273.

Koentjoro, W. 2011. Upah dalam Perspektif Islam. Jurnal Prestasi, Vol. 8 No. 2. Hal 1

Lana Sularto, D. W. 2015. Adopsi Teknologi Informasi untuk Pencatatan Transaksi Pada Usaha Kecil dan Menengah Restoran di Wilayah Jakarta, Bogor, Depok, Tangerang dan Bekasi. Prosiding PESAT (Psikologi, Ekonomi, Sastra, Arsitektur \& Teknik Sipil, Vol. 6 ISSN: 1858-2559. hal: 269.

Malahayati. 2010. Rahasia Sukses Bisnis Rasulallah, Cet. pertama. Yogyakarta: Penerbit Jogja Great Publisher. 
Markas. 2014. Urgensi Sifat Jujur dalam Berbisnis. Jurnal PILAR, Vol. 2 No. 2. Hal: 171

Musfiqon. 2012. Metode Penelitian Pendidikan. Jakarta: PT Prestasi Pustakarya.

Nawatmi, S. 2010. Etika Bisnis dalam Perspektif Islam. Jurnal Fokus Ekonomi, Vol. 9 No. 1. hal: 54, 57

Nurcholifah, Ita. 2015. Membangun Muslim Entrepreneurship: Dari Pendekatan Konvensional Ke Pendekatan Syariah. Jurnal Al-Mashlahah Jurnal Ilmu Syariah. Volume 5 Nomor 1 hal. 14

Saifullah, M. 2011. Etika Bisnis Islami dalam Praktek Bisnis Rasulallah. Jurnal Walisongo, Volume 19 Nomor 1. hal: 145.

Sakdiah. 2016. Karakteristik Kepemimpinan dalam Islam (Kajian Historis Filosofis) Sifat-Sifat Rasulallah. Jurnal Al-Bayan, Vol. 22 No. 33. Hal 31-32
Sijabat, S. 2008. Potret Iklim Usaha Pemberdayaan UMKM. INFOKOP, volume 16. Hal. 3

Sugiyono. 2013. Metode Penelitian Kuantitatif, Kualitatif dan Kombinasi (Mixed Methods). Bandung: Alfabeta.

Susilo, Y. S. 2007. Pertumbuhan Usaha Industri Kecil-Menengah (IKM) dan Faktor-faktor yang Mempengaruhinya. Jurnal Eksekutif, Volume 4 Nomor 2. Hal 306

Tambunan, T. 2012. Usaha Mikro Kecil dan Menengah di Indonesia: Isu-isu Penting. Jakarta: LP3ES.

Undang-undang Republik Indonesia No. 20 Tahun 2008 tentang Usaha Mikro, Kecil dan Menengah

Yusri, M. 2009. Kajian Undang-Undang Pelindungan Konsumen dalam perspektif Hukum Islam. Jurnal Ulumuddin, Volume V. hal: 367-368

Zahroh, A. 2014. Spiritual Entrepreneur. Jurnal Iqtishaduna, Vol. 4 No. 1. Hal: 112-116. 


\section{Ucapan Terima Kasih}

Dewan Redaksi serta Redaksi Pelaksana Jurnal Syarikah mengucapkan terima kasih dan penghargaan setinggi-tingginya kepada para pakar yang telah berperan sebagai mitra bebestari pada penerbitan Jurnal Syarikah Volume 3 Nomor 1 Juni Tahun 2017.

$$
\text { Dr. Nurul Huda, M.Si }
$$

Semoga kerjasama yang baik dapat terus berlangsung di masa-masa yang akan datang untuk lebih meningkatkan kualitas Jurnal Syarikah. 


\title{
PANDUAN BAGI PENULIS JURNAL SYARIKAH: JURNAL EKONOMI ISLAM
}

\author{
Pemutakhiran Juni 2017
}

\section{RUANG LINGKUP}

Jurnal Syarikah: Jurnal Ekonomi Islam mendorong pengembangkan ilmu pengetahuan dan teknologi dalam bidang Ekonomi Islam melalui penerbitan karya ilmiah berbasis hasil penelitian (orisinal).

\section{JENIS NASKAH}

Jenis naskah yang dipublikasikan adalah naskah orisinal hasil penelitian yang belum pernah dipublikasikan atau tidak sedang dalam proses publikasi oleh media publikasi lain dan terbebas dari plagiarisme. Bahasa publikasi adalah bahasa Indonesia atau bahasa Inggris. Setiap naskah yang masuk ke dewan redaksi akan menjalani proses peer-review.

Naskah hasil penelitian harus didasarkan atas data hasil penelitian orisinal yang belum dipublikasikan dan dianalisis menggunakan metode statistik. Naskah hasil penelitian yang disajikan secara deskriptif tanpa rancangan penelitian yang dikontrol oleh peneliti, naskah hasil penelitian yang hanya berupa pengulangan (replikasi) dari hasil penelitian yang telah dipublikasikan, misalnya hanya kondisi geografisnya yang berbeda, tidak akan dipertimbangkan untuk dipublikasikan. Naskah bernomor seri tidak dapat diterima, kecuali disampaikan dan disajikan pada waktu yang bersamaan.

\section{PENGIRIMAN NASKAH}

Naskah yang diajukan ditujukan ke Pimpinan Dewan Redaksi Jurnal Syarikah, melalui e-mail ke tuti.kurnia@unida.ac.id. Naskah dimaksud harus dilengkapi dengan Surat Pernyataan Orisinalitas dan Pemindahan Hak Publikasi yang ditandatangi oleh semua penulis.

\section{KONVENSI DAN KETAATASASAN}

Naskah harus ditulis dengan tema font Time New Roman 12, spasi ganda, batas tepi $2,5 \mathrm{~cm}$, halaman berukuran A4, menggunakan program microsoft office word. Naskah ditulis tidak lebih dari 7.500 kata berdasarkan urutan bagian berikut:

1) Judul (Title): JUDUL berbahasa Indonesia dan Inggris, Nama Penulis, Alamat Penulis, Penulis untuk Korespondensi, dan Judul Singkat (Running Head).

2) Tajuk Utama (main section headings): ABSTRACT, ABSTRAK, PENDAHULUAN, MATERI DAN METODE, HASIL, PEMBAHASAN, KESIMPULAN DAN IMPLIKASI, UCAPAN TERIMA KASIH, DAFTAR PUSTAKA.

3) Lampiran: Tabel, Grafik, dan Gambar.
Judul naskah harus berhuruf tebal dan kapital, ditulis pada bagian tengah dari baris tersendiri. Tajuk dan subtajuk ditulis pada baris tersendiri, mulai dari batas tepi kiri badan teks. Tajuk berhuruf tebal dan kapital. Subtajuk berhuruf tebal dan huruf kapitalnya hanya pada awal kata. Jarak antara tajuk dan subtajuk adalah 10 point (pt) sedangkan jarak antara tajuk atau subtajuk dan badan teks adalah 6 pt. Pembeda paragraf dimulai pada paragraf kedua setelah tajuk atau subtajuk dan dicirikan oleh baris pertamanya yang berjarak $0,5 \mathrm{~cm}$ dari batas tepi kiri badan teks.

Naskah yang terlalu panjang atau terlalu pendek akan dikembalikan kepada penulis. Sebagai pedoman, 7.500 kata setara dengan 34 halaman ukuran A4, yang ditulis dengan tema font Time New Roman 12, spasi ganda, marjin $2,5 \mathrm{~cm}$ dari semua tepi halaman. Judul tidak lebih dari 12 kata, Judul Singkat tidak lebih dari 50 karakter, Abstract dan Abstrak masing-masing tidak lebih dari 250 kata, key words dan kata kunci masing-masing 5 kata, dan Pendahuluan tidak lebih dari 500 kata.

\section{Judul}

Judul harus ringkas dan padat informasi, tidak memuat kata singkatan, dan memuat hal-hal berikut:

a) membangkitkan minat bagi pembaca yang memindai jurnal atau daftar judul jurnal.

b) Menyediakan informasi yang cukup bagi pembaca untuk menilai relevansi suatu naskah dengan minatnya

c) Memasukkan kata kunci atau frasa yang dapat digunakan dalam mengindeks dan menarik informasi tentang penelitian yang dilakukan.

d) Menghindari kata-kata yang tidak penting, seperti "suatu studi kasus ...." atau "suatu tinjauan empiris tentang ....". Hal-hal tersebut lebih tepat ditulis pada subbagian Materi dan Metode.

e) Tidak boleh memuat kata tempat, seperti “.... di Bogor"

\section{Nama dan Alamat Penulis}

Nama dan alamat penulis harus disajikan seperti contoh berikut:

G. PraditinKa ${ }^{1, a}$ dan W. munawar ${ }^{2}$

${ }^{1}$ Lembaga Penelitian dan Pengembangan Universitas Djuanda, Jl. Tol Ciawi Kotak Pos 35 Bogor 16720.

${ }^{2}$ Program Studi Ekonomi Islam Fakultas Ekonomi Islam Universitas Djuanda, Jl. Tol Ciawi No. 1 Kotak Pos 35 Bogor 16720.

aKorespondensi: Tuti Kurnia. Telepon: 0818106472; E-mail: tuti.kurnia@unida.ac.id 


\section{Judul Singkat (running head)}

Penulis harus menuliskan judul singkat tidak lebih dari 50 karakter termasuk ketukan kosong.

\section{Abstract dan Abstrak}

Abstract ditulis dalam bahasa Inggris baku secara konsisten (American English atau British English). Abstrak ditulis dalam bahasa Indonesia yang baik dan benar, menggunakan kata-kata baku. Baik abstract maupun abstrak dibuat dalam satu paragraf utuh tanpa ada acuan pustaka atau perujuk tabel dan/atau gambar, tidak lebih dari 250 kata. Isinya harus memuat masalah penting yang akan dipecahkan, tujuan, metode, hasil, kesimpulan, dan tidak boleh terlalu padat dengan angka-angka. Penyingkatan kata tidak diperkenankan kecuali kata dimaksud akan digunakan lebih dari satu kali..

\section{Keywords dan Kata Kunci}

Keywords (berbahasa Ingris) dan Kata kunci (berbahasa Indonesia), masing-masing tidak lebih dari lima kata dan sebaiknya tidak sama dengan kata-kata yang terdapat dalam judul naskah. Jika tidak memadai, dewan redaksi akan mengubahnya atas persetujuan penulis.

\section{Pendahuluan}

Pendahuluan yang ditulis tidak lebih dari 500 kata, harus menjelaskan isu-isu mutakhir yang mengarah pada pentingnya penelitian yang dilakukan, tujuan penelitian dinyatakan dengan jelas, dan menuliskan state of the art dari topik penelitiannya sehingga gambaran utama penelitiannya menjadi jelas bagi para pembaca. Namun, acuan pustaka dalam pendahuluan harus dibatasi karena bukan merupakan pembahasan awal.

\section{Materi dan Metode}

Materi dan metode penelitian harus dijelaskan secara terperinci pada bagian ini sehingga memungkinkan bagi peneliti lain untuk mengulang penelitian ini. Materi atau bahan yang digunakan tidak diperinci secara terpisah, melainkan harus terintegrasi dengan prosedur penelitian. Misalnya, .."responden diminta mengisi daftar pertanyaan menggunakan pensil 2B dan memilih satu dari tiga poster yang diperlihatkan oleh peneliti...", tidak perlu memerincinya seperti berikut: " Materi penelitian terdiri atas: daftar pertanyaan, pensil 2B, dan poster. Jika penelitian menggunakan produk berpemilik (seperti paten) untuk pembanding, produk dimaksud harus dituliskan dalam nama yang baku atau dituliskan merk dagangnya di dalam tanda kurung jika dianggap membantu memperjelas pemahaman pembaca, namun syaratnya harus mendapat izin tertulis dari pemilik produk dimaksud sebelum dipublikasikan. Model, tipe, merk, dan produsen peralatan yang digunakan dalam penelitian harus dijelaskan. Metode dan model analisis statistik harus jelas sehingga memungkinkan bagi peneliti lain untuk melakukan pengulangan.

Sistematika penulisannya diurutkan sebagai berikut: materi, rancangan percobaan dan perlakuan, prosedur pelaksanaan penelitian, analisis laboratorium, dan analisis statistik. Sistematika ini tidak kaku, dapat disesuaikan dengan ciri bidang keilmuan. Misalnya, untuk penelitian agribisnis yang tidak ada analisis laboratoriumnya, tidak perlu ada analisis laboratorium. Sebaliknya, subbagian lainnya dapat ditambahkan sesuai kebutuhan.

\section{Hasil dan Pembahasan}

Hasil penelitian, termasuk hasil analisis statistiknya dipaparkan secara terperinci dalam bagian ini. Ilustrasi, jika diperlukan dapat disajikan dalam bentuk tabel dan/atau gambar. Tabel dan gambar harus sederhana, informatif, mudah dipahami, dan mandiri, dalam arti tabel atau gambar dimaksud harus bisa menjelaskan kepada pembaca sehingga pembaca tidak harus membaca tulisannya untuk memahaminya. Hal yang sudah dijelaskan dalam tabel atau gambar tidak perlu diulang dalam tulisan. Tabel dan gambar dimuat pada halaman terpisah darik teks.

Hasil penelitian selanjutnya dibahas dengan cara membandingkannya dengan hasil penelitian pada topik serupa dari peneliti sebelumnya untuk mengungkap keajegannya (konsistensinya) apakah konsisten (sama) atau berbeda, lalu jelaskan alasan ilmiahnya atas hasil dimaksud secara lugas dan tuntas sehingga memperjelas posisi hasil penelitiannya. Selanjutnya, temuan hasil penelitian diungkapkan disertai kelebihan dan kelemahannya, jika ada. Ungkapan temuan hasil penelitian ini akan mempermudah dalam menyimpulkan hasil penelitian.

Data rataan perlakuan harus ditulis dengan galat bakunya (standard errors). Tingkat signifikansi statistik dapat dinyatakan dalam $\mathrm{P}<0,05, \mathrm{P}<0,01$, dan $\mathrm{P}<0,001$. Khusus pada tabel, tingkat signifikansi dimaksud, berturut-turut dapat ditulis dengan *, **, dan ${ }^{* * *}$ sedangkan pada tabel dan grafik, perbedaan antarperlakuan dapat ditunjukkan dengan huruf $a, b$ untuk $\mathrm{P}<0,05$ dan $\mathrm{A}$, B untuk $\mathrm{P}<0,01$.

\section{Kesimpulan dan Implikasi}

Kesimpulan memuat temuan hasil penelitian yang mencerminkan kebaruan, keorisinilan, kepioneran, keuniversalan, dan kontribusi ilmiah dalam pengembangan ilmu pengetahuan dan teknologi. Pernyataan dalam simpulan terbebas dari frasa atau istilah statistik, seperti " ..berpengaruh nyata $(\mathrm{P}<0,05) "$

Penulis harus menjelaskan implikasi hasil penelitiannya dalam pengembangan keilmuan, dan dampaknya terhadap lingkungan, sosial, budaya, 
ekonomi, politik, dan/atau hukum. Implikasi dipaparkan dalam bahasa yang sederhana agar pembaca noncendekia dapat memahaminya dengan mudah.

\section{Ucapan Terima Kasih}

Ucapan terima kasih hanya wajib ditulis jika penelitian didukung (biaya, sarana, tenaga) oleh instansi atau individu, atau penelaah sejawat jika naskahnya ditelaah sebelum dipublikasikan.

\section{Daftar Pustaka}

Penulis bertanggung jawab atas kebenaran semua sumber pustaka yang dirujuk dan dituliskan dalam Daftar Pustaka dan yang diacu dalam teks. Sumber pustaka sangat dianjurkan menggunakan terbitan terbaru (10 tahun terakhir), dan disajikan secara alfabet dan dituliskan menurut format nama tahun. Beberapa format dan contoh penulisannya antara lain:

Naskah jurnal atau abstrak. Format: Nama Penulis. Tahun. Judul. Nama Jurnal. Volume: Halaman. Contoh:

Rahmawati R, G Praditina dan RA Munjin. 2009. Model pelayanan rumah sakit berbasis karakteristik sosial ekonomi masyarakat untuk meningkatkan kepuasan pasien. Jurnal Humaniora. 1(1): 18-29.

Buku. Format: Nama Penulis atau Nama Editor atau Nama Lembaga. Tahun. Judul. Edisi, Nama Penerbit, Tempat Penerbitan. Contoh:

Roestamy M. 2011. Konsep-konsep hukum kepemilikan properti bagi asing (dihubungkan dengan hukum pertanahan). Edisi pertama. PT. Alumni. Bandung.

Bab buku atau proseding. Format: Nama Penulis. Tahun. Judul. Dalam: Judul buku atau proseding (Nama Editor). Volume: Halaman. Nama Penerbit, Tempat Penerbitan. Contoh:

Goulet D. 2000. Ethics, culture and development: livestock, poverty and quality of rural life. In: Livestock, ethics and quality of life (eds. Hodges, John and Han, In K). 131-154. CABI Publishing, New York, NY 10016, USA.

Laporan pada pertemuan ilmiah (konferensi, workshop, dll) yang tidak tercakup dalam buku atau proseding. Format: Nama Penulis. Tahun. Judul. Judul atau Nama Pertemuan Ilmiah, Tempat Pertemuan. Jumlah halaman. Contoh:

Jalal F. 2011. Tantangan dan peluang pendidikan di Indonesia. Orasi Ilmiah. Wisuda XXVI Sarjana dan Pascasarjana Universitas Djuanda, Bogor. 16 hal.

Tesis atau Disertasi. Format: Nama Penulis. Tahun. Judul. Tesis atau Disertasi. Nama Perguruan Tinggi, Tempat Perguruan Tinggi. Contoh:

Roestamy M. 2008. Kepastian hukum atas kepemilikan rumah dan bangunan gedung oleh investor asing dikaitkan dengan asas nasionalitas dalam sistem hukum pertanahan Indonesia. Disertasi. Program Studi Doktor Ilmu Hukum Fakultas Hukum Universitas Padjadjaran, Bandung.

Karya Ilmiah Lepas yang dimuat pada Website. Karya ilmiah lepas yang dimuat pada website hanya dapat digunakan jika literatur standard lainnya tidak tersedia. Format: Nama Penulis. Tahun. Judul. Diunduh tanggal-bulan-tahun dari http://.... Contoh:

Bryant P. 1999. Biodiversity and Conservation. Retrieved October 4, 1999 from http://darwin bio.uci.edu/ sustain/bio65/Titlpage.htm

\section{Penulisan Nama Penulis yang Diacu pada Teks}

Nama penulis yang diacu di dalam teks tidak diperkenankan menggunakan footnote. Jika jumlah penulis kurang dari tiga nama penulis ditulis semua, jika jumlah penulis tidak kurang dari tiga, hanya penulis utama yang ditulis dan diikuti dengan et al. Contoh: Syamsah (2010) menyimpulkan bahwa pajak dan zakat memiliki hubungan reduktif dan deduktabel. Parameter kualitas layanan puskesmas secara simultan mempengaruhi kepuasan pasien (Yuningsih dan Maulana 2010). Kekurangan dari kualitas pelayanan rumah sakit dapat diatasi apabila rumah sakit memperhatikan karakteristik pasien (Rahmawati et al. 2010). Tingkat kepuasan pasien menjadi indikator penting dalam mengukur kualitas pelayanan kesehatan (Yuningsih dan Maulana 2010; Rahmawati et al. 2010).

\section{Tabel}

Tabel harus dibuat sesederhana dan sesedikit mungkin, namun sekurang-kurangnya harus memuat dua baris data. Jika hanya ada satu baris data, maka penyajiannya harus menggunakan grafik. Garis horisontal tabel hanya boleh untuk mencirikan batas baris teratas (heading) dan garis terbawah dari badan tabel, sedangkan garis-garis kolom tabel tidak diperkenankan. Tabel dibuat dengan menggunakan fungsi tabel dalam program microsoft office word. Judul tabel harus ringkas, jelas, dan informatif, diberi nomor urut angka arab, huruf kapital hanya pada huruf pertama judul tabel kecuali beberapa nama diri, dan ditempatkan di atas badan tabel. Lazimnya, peubah disajikan dalam baris dan perlakuan disajikan pada kolom tabel. Keterangan tabel disajikan di bagian bawah badan tabel tanpa menuliskan kata keterangan. Di dalam teks, nomor tabel harus dirujuk, misalnya: kepribadian dalam pandangan Islam merupakan integrasi sistem kalbu, akal, dan nafsu (Tabel 1). Judul tabel, tabel dan keterangan tabel disajikan pada halaman tersendiri setelah Daftar Pustaka. Lebar tabel $80 \mathrm{~mm}$ atau $160 \mathrm{~mm}$. Jangan menyisipkan tabel pada bagian teks. Contoh Tabel lebar $80 \mathrm{~mm}$ : 
Table 1 Persentase distribusi daya fitrah nafsani dalam pembentukan kepribadian

\begin{tabular}{lccc}
\hline \multirow{2}{*}{$\begin{array}{l}\text { Daya fitrah } \\
\text { nafsani }\end{array}$} & \multicolumn{3}{c}{ Tingkat kepribadian (\%) } \\
\cline { 2 - 4 } & Muthmainnah & Lawwamah & Ammarah \\
\hline Kalbu & 55 & 30 & 15 \\
Akal & 30 & 40 & 30 \\
Nafsu & 15 & 30 & 55 \\
\hline
\end{tabular}

Format tabel diubahsuai dari Sulaiman H (2010) tanpa mengubah substansi.

\section{Gambar dan Grafik}

Gambar dan grafik dibuat dalam format JPEG dan hanya diperbolehkan jika data hasil penelitian tidak dapat disajikan dalam bentuk tabel. Grafik yang dibuat dengan program microsoft office excel harus diubahsuiakan menjadi format JPEG dengan kualitas gambar yang layak cetak. Ukuran lebar gambar adalah $80 \mathrm{~mm}$ atau $160 \mathrm{~mm}$. Judul gambar harus ringkas, jelas, dan informatif, diberi nomor urut angka arab, huruf kapital hanya pada huruf pertama judul gambar kecuali beberapa nama diri, dan ditempatkan di bagian bawah gambar. Contoh gambar berformat JPEG lebar $80 \mathrm{~mm}$ (Gambar 1).

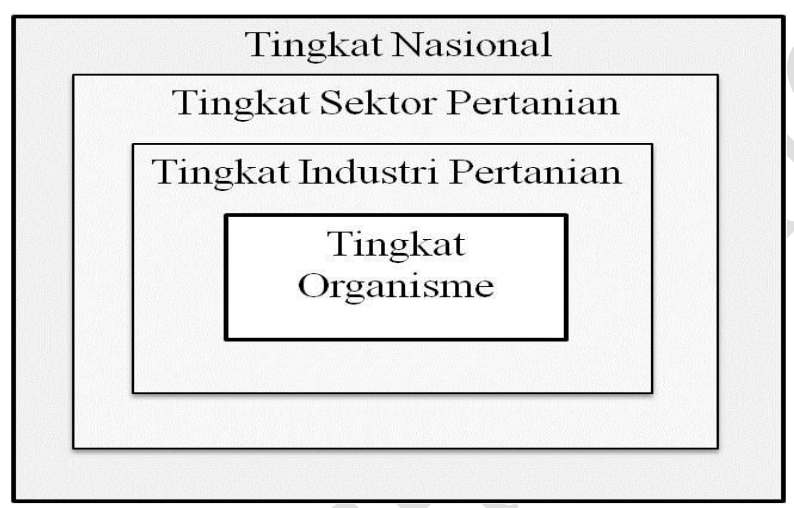

Gambar 1 Empat tingkat domain untuk menghadapi agroterorisme (ubahsuai dari Kohnen 2000).
Keterangan gambar ditulis setelah dan merupakan bagian integral dari judul gambar. Gambar dan judul gambar disajikan pada halaman tersendiri setelah halaman tabel. Di dalam teks, seluruh nomor gambar harus dirujuk secara berurutan seperti nomor tabel. Gambar dicetak hitam putih dan jika penulis menghendaki gambar berwarna, maka biaya pencetakan menjadi tanggung jawab penulis.

\section{Cetak Lepas}

Penulis yang naskahnya telah dipublikasikan akan mendapatkan satu Jurnal Humaniora dan dua eksemplar cetak lepas (reprint) artikelnya. Penulis yang ingin menambah jumlah jurnal dan cetak lepasnya dapat memesannya ke Dewan Redaksi melalui telefon atau email. Berikut ini adalah daftar harga Jurnal Humaniora dan cetak lepasnya, belum termasuk ongkos kirim.

Daftar harga Jurnal Humaniora dan cetak lepasnya

\begin{tabular}{lll}
\hline Jumlah & $\begin{array}{l}\text { Jurnal Syarikah } \\
\text { (Rp/eksemplar) }\end{array}$ & $\begin{array}{l}\text { Cetak lepasnya*) } \\
\text { (Rp/eksemplar) }\end{array}$ \\
\hline $1-5$ & 75.000 & 30.000 \\
6 atau lebih & 60.000 & 25.000 \\
\hline
\end{tabular}

${ }^{*}{ }^{6}$ pemesanan minimal 5 eksemplar. 


\section{SURAT PERNYATAAN ORISINALITAS ${ }^{1}$}

Kepada

\section{Dewan Editor Jurnal Syarikah}

Program Studi Ekonomi Islam Fakultas Ekonomi islam

Universitas Djuanda Bogor

Bersama ini kami mengajukan naskah,

\section{Judul :}

Penulis:

\begin{tabular}{|c|c|c|c|c|}
\hline No & $\begin{array}{c}\text { Penulis lengkap dengan } \\
\text { gelar akademik }\end{array}$ & Nama dan Alamat Institusi, email & $\begin{array}{l}\text { Tanda } \\
\text { Tangan }\end{array}$ & Tanggal \\
\hline
\end{tabular}

1

2

3

untuk dipublikasikan pada Jurnal Syarikah. Kami menyatakan bahwa naskah dimaksud adalah naskah orisinal hasil penelitian kami yang belum pernah dipublikasikan, tidak sedang dalam proses publikasi oleh media publikasi lainnya, tidak akan diajukan ke media publikasi lainnya selama dalam proses penelaahan (review) kecuali jika kami menarik secara resmi naskah dimaksud dari Dewan Redaksi Jurnal Syarikah, terbebas dari plagiarisme, dan kami bertanggung jawab atas seluruh substansi naskah berjudul tersebut di atas yang kami tulis.

Nama penulis untuk korespondensi:

Telepon/(hanya digunakan untuk keperluan korespondensi)

Email: (untuk keperluan korespondensi dan akan dicantumkan pada artikel yang

dipublikasikan)

Terima kasih atas perhatian dan kerjasamanya.

Tanggal:

Penulis:

Tanda tangan:

\footnotetext{
${ }^{1}$ Dikirim ke Dewan Redaksi Jurnal Syarikah, Program Studi Ekonomi Islam Fakultas Ekonomi Islam Universitas Djuanda Bogor, Gedung B Lantai IV Jl Tol Ciawi No. 1 Kotak Pos 35 Ciawi Bogor 16720, difaksimilikan ke 02518240985, dan hasil scanning-nya diemailkan ke Jurnal.Syarikah@unida.ac.id.
} 


\section{SURAT PERNYATAAN PEMINDAHAN HAK CIPTA ${ }^{2}$}

Yang bertanda tangan di bawah ini adalah penulis naskah yang berjudul:

yang diajukan untuk dipublikasikan pada Jurnal Syarikah: Jurnal Ekonomi Islam ISSN 2442-4420 menyatakan bahwa:

Kami bersedia memindahkan hak publikasi, distribusi, reproduksi, dan menjual naskah kamiyang berjudul tersebut di atas sebagai bagian dari Jurnal Syarikah kepada Dewan Redaksi Jurnal Syarikah ISSN 2442-4420

Demikian surat pernyataan ini saya buat dengan sadar, penuh rasa tanggung jawab, dan tanpa paksaan dari pihak mana pun!

\begin{tabular}{llcc}
\hline No & $\begin{array}{l}\text { Nama Penulis (lengkap } \\
\text { dengan gelar akademik) }\end{array}$
\end{tabular}$\quad$ Nama dan Alamat Institusi, email $\begin{gathered}\text { Tanda } \\
\text { Tangan }\end{gathered}$ Tanggal




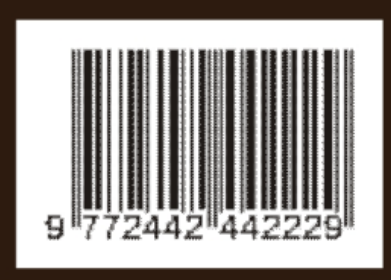

